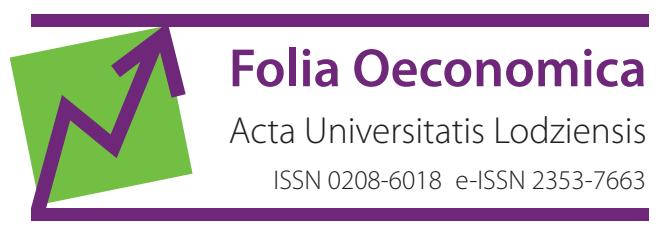

www.czasopisma.uni.lodz.pl/foe/

$1(340) 2019$

DOI: http://dx.doi.org/10.18778/0208-6018.340.04

\title{
Katarzyna Klimczak
}

Szkoła Główna Handlowa w Warszawie, Instytut Rachunkowości, Zakład Rachunkowości

Informatycznej, katarzyna.klimczak@sgh.waw.pl

\section{Korzyści wynikające z zastosowania XBRL na potrzeby raportowania na rynkach kapitałowych w świetle stanowisk nadzorców rynków oraz badań naukowych}

\begin{abstract}
Streszczenie: Celem artykułu jest identyfikacja najważniejszych korzyści związanych z zastosowaniem XBRL na potrzeby raportowania na rynkach kapitałowych, wymienianych i analizowanych przez nadzorców tych rynków, a także weryfikowanych w empirycznych badaniach naukowych. Analizy i badania wskazują, że zastosowanie standardu XBRL jako narzędzia wspomagającego raportowanie finansowe może prowadzić do usprawnienia przepływu informacji, zwiększenia: jakości i ilości danych dostępnych dla odbiorców, porównywalności sprawozdań finansowych, a także zdolności przetwarzania i analizowania danych przez ich użytkowników. Standard może mieć duży wpływ na funkcjonowanie rynku kapitałowego, prowadząc między innymi do zmniejszenia asymetrii informacyjnej między uczestnikami rynku, redukcji kosztów kapitału własnego, zwiększenia płynności rynku. Korzyści z zastosowania XBRL mogą być odnotowywane przez wszystkich uczestników rynków kapitałowych - przedsiębiorstwa finansujące swoją działalność za pośrednictwem tych rynków, regulatorów rynków, inwestorów i analityków.
\end{abstract}

Słowa kluczowe: XBRL, raportowanie, rynki kapitałowe, korzyści

JEL: M41 


\section{Wprowadzenie}

Od końca XX wieku trwały prace nad stworzeniem formatu bazującego na specyfikacji XML i pokrewnych technologiach, który umożliwiałby elektroniczną wymianę informacji finansowych. Efektem tych prac jest XBRL - Extensible Business Reporting Language (Boritz, No, 2003: 17-18).

Standard ten jest coraz powszechniej wykorzystywany na świecie w różnorodnych procesach sprawozdawczych, między innymi na potrzeby sprawozdawczości podatkowej, statystycznej, bankowej, a także w ramach dobrowolnego czy obowiązkowego raportowania na rynkach kapitałowych. Wśród krajów wykorzystujących XBRL znajdują się między innymi Stany Zjednoczone, Wielka Brytania, Francja, Niemcy, Irlandia, Dania, Japonia, Australia, Belgia, Peru, Hiszpania, Singapur, Chile (www.xbrl.org; Qualitative, quantitative..., 2016: 10-14).

Przedmiotem rozważań $\mathrm{w}$ niniejszym artykule są potencjalne korzyści wynikające $\mathrm{z}$ zastosowania XBRL na potrzeby raportowania na rynkach kapitałowych.

W pierwszej części artykułu skoncentrowano się na analizie stanowisk, raportów, dokumentów konsultacyjnych związanych z XBRL, przedstawianych przez nadzorców rynków kapitałowych. Na potrzeby analizy wybrano Amerykańską Komisję Papierów Wartościowych i Giełd (US Securities and Exchange Commission-US SEC) oraz Europejski Urząd Nadzoru Giełd i Papierów Wartościowych (The European Securities and Markets Authority - ESMA). W ostatnim czasie US SEC zaakceptowała nowe założenia dotyczące zastosowania XBRL na potrzeby raportowania na amerykańskim rynku kapitałowym, co było kolejnym krokiem w trwających od dawna działaniach na rzecz stosowania standardu XBRL w Stanach Zjednoczonych. Z kolei w Unii Europejskiej dobiegają końca prace nad wdrożeniem rozwiązań przewidujących obowiązek przygotowywania rocznych raportów finansowych w standardzie XBRL przez spółki notowane na europejskich rynkach kapitałowych.

Na potrzeby drugiej części artykułu dokonano przeglądu artykułów naukowych dotyczących standardu XBRL w celu identyfikacji najczęściej wymienianych pozytywnych efektów jego zastosowania. Następnie wyselekcjonowano te badania, które zostaną przedstawione jako przykładowe empiryczne weryfikacje zidentyfikowanych korzyści. 


\section{Korzyści wynikające z zastosowania XBRL na potrzeby raportowania - stanowisko nadzorców rynków kapitałowych}

W Stanach Zjednoczonych przedsiębiorstwa podlegające nadzorowi US SEC od początku lat dziewięćdziesiątych ubiegłego stulecia raportowały w systemie EDGAR (Electronic Data Gathering, Analysis and Retrieval System). US SEC cały czas prowadziła prace nad unowocześnieniem zasad raportowania z wykorzystaniem nowoczesnych technologii, czego efektem stał się plan zamiany systemu EDGAR na system IDEA (Interactive Data Electronic Applications), oparty na standardzie XBRL. Od 2005 roku przedsiębiorstwa mogły wykorzystywać standard XBRL dobrowolnie. Na początku 2009 roku opublikowano ostateczne zasady wdrożenia programu XBRL. Na ich podstawie od 13 kwietnia 2009 roku wprowadzono obowiązek raportowania w XBRL w odniesieniu do 500 największych przedsiębiorstw krajowych i zagranicznych sporządzających sprawozdania finansowe zgodnie z US GAAP. Natomiast od 2011 roku w Stanach Zjednoczonych wszystkie spółki publiczne zostały zobligowane do przesyłania swoich sprawozdań finansowych do US SEC w standardzie XBRL (Interactive Data..., 2009: 4-29).

Według US SEC dostarczanie sprawozdań finansowych w interaktywnym formacie danych (Interactive Data..., 2009: 5-10):

1) umożliwia inwestorom i innym użytkownikom bardziej sprawne i dynamiczne poszukiwanie i przetwarzanie informacji;

2) zwiększa porównywalność sytuacji majątkowo-finansowej przedsiębiorstw i ich dokonań (porównywalność między przedsiębiorstwami, okresami sprawozdawczymi i branżami);

3) daje możliwość automatyzacji obowiązków sprawozdawczych i procesów przetwarzania informacji, co może zwiększać szybkość, dokładność i użyteczność finansowych ujawnień.

Wśród najważniejszych korzyści związanych z XBRL US SEC wymienia zapewnienie użytkownikom większej ilości, tańszych, bardziej aktualnych, poprawnych danych finansowych oraz zwiększenie ich porównywalności i możliwości interpretacji (Interactive Data..., 2009: 125-131).

Po pierwsze, zastosowanie standardu XBRL może zwiększyć jakość i ilość informacji dostępnej dla użytkowników (tabela 1).

Po drugie, narzucenie obowiązku raportowania interaktywnych danych może zmniejszyć czas i koszt przetwarzania informacji przez przedsiębiorstwa oraz czas i koszt dotarcia do informacji przez użytkowników. To obniżenie kosztów powoduje również, że dostęp do danych jest o wiele szerszy - ze względu na mniejsze koszty gromadzenia danych są one również dostępne dla mniejszych inwestorów (tabela 2). 
Tabela 1. Wpływ zastosowania XBRL na jakość i ilość informacji dostępnych dla użytkowników sprawozdań finansowych

\begin{tabular}{|c|c|}
\hline $\begin{array}{l}\text { XBRL } \\
\text { a jakość i ilość } \\
\text { informacji }\end{array}$ & Wyjaśnienie \\
\hline \multirow{3}{*}{$\begin{array}{l}\text { Więcej informa- } \\
\text { cji dla użytkow- } \\
\text { ników sprawoz- } \\
\text { dań finansowych }\end{array}$} & $\begin{array}{l}\text { W wyniku interaktywnego tagowania danych zwiększa się ilość informacji } \\
\text { finansowych dostępnych w formie elektronicznej, w łatwo odczytywalnym } \\
\text { formacie. }\end{array}$ \\
\hline & $\begin{array}{l}\text { Dane finansowe mniejszych emitentów mogą być włączone do baz danych } \\
\text { firm, które oferują je w celach komercyjnych, a które wcześniej pomijały } \\
\text { informacje na temat mniejszych emitentów ze względu na wysokie koszty } \\
\text { pozyskania danych. }\end{array}$ \\
\hline & $\begin{array}{l}\text { Inwestorzy zyskują łatwy dostęp do większej ilości danych finansowych } \\
\text { dotyczących większej liczby firm. }\end{array}$ \\
\hline $\begin{array}{l}\text { Lepsza jakość } \\
\text { informacji }\end{array}$ & $\begin{array}{l}\text { Zobligowanie przedsiębiorstw do dostarczania interaktywnych danych może } \\
\text { poprawić jakość informacji finansowych dostępnych dla użytkowników } \\
\text { końcowych. }\end{array}$ \\
\hline
\end{tabular}

Źródło: opracowanie własne na podstawie Interactive Data..., 2009: 125-127

Tabela 2. Wpływ zastosowania XBRL na koszt i aktualność informacji finansowych

\begin{tabular}{|l|l|}
\hline $\begin{array}{c}\text { XBRL a koszt } \\
\text { i aktualność } \\
\text { informacji }\end{array}$ & \multicolumn{1}{c|}{ Wyjaśnienie } \\
\hline \multirow{5}{*}{$\begin{array}{l}\text { Tańsze i bardziej } \\
\text { aktualne infor- } \\
\text { macje }\end{array}$} & $\begin{array}{l}\text { Tradycyjne raporty finansowe są udostępniane inwestorom w dokumentach } \\
\text { sformatowanych tekstowo, które wymagają ręcznego wprowadzania danych } \\
\text { do formatu umożliwiającego analizę statystyczną i agregację. Inwestorzy } \\
\text { są zatem zmuszeni do ponoszenia nakładów czasowych (w celu ręcznego } \\
\text { zbierania danych) lub też finansowych (związanych z wykorzystaniem usług } \\
\text { firm specjalizujących się w procesie pozyskiwania informacji). Raportowa- } \\
\text { nie interaktywne może obniżyć koszt gromadzenia danych oraz przyspie- } \\
\text { szyć analityków, inwestorów i innych użytkowników raportów finan- }\end{array}$ \\
\cline { 2 - 3 } & $\begin{array}{l}\text { Niższe koszty pozyskania danych pozwolą inwestorom albo na ich pozy- } \\
\text { skanie we własnym zakresie, albo na ich zakup za niższą cenę. W związku } \\
\text { z tym mniejsi inwestorzy będą mieli mniej barier informacyjnych, które od- } \\
\text { dzielają ich od większych inwestorów, dysponujących większymi zasobami } \\
\text { finansowymi. }\end{array}$ \\
\cline { 2 - 3 } & $\begin{array}{l}\text { Wdrożenie interaktywnego raportowania może być dla emitentów okazją } \\
\text { do zautomatyzowania procesów dokumentacji i przetwarzania informacji } \\
\text { biznesowych, co może nie tylko zwiększyć szybkość, dokładność i uży- } \\
\text { teczność ujawniania informacji finansowych, ale też zmniejszyć ponoszone } \\
\text { przez emitentów koszty archiwizacji i przetwarzania informacji. }\end{array}$ \\
\hline
\end{tabular}

Źródło: opracowanie własne na podstawie Interactive Data..., 2009: 127-130 
Po trzecie, efektem zastosowania XBRL może być zmniejszenie liczby błędów w raportach finansowych (przez automatyczną przeróbkę danych oraz wewnętrzne systemy walidacji danych eliminowane jest prawdopodobieństwo wystąpienia błędu w raportach) (tabela 3).

Tabela 3. Wpływ zastosowania XBRL na poprawność informacji finansowych

\begin{tabular}{|l|l|}
\hline $\begin{array}{c}\text { XBRL } \\
\text { a poprawność } \\
\text { informacji }\end{array}$ & \multicolumn{1}{c|}{ Wyjaśnienie } \\
\hline \multirow{2}{*}{$\begin{array}{l}\text { Bardziej } \\
\text { poprawne } \\
\text { informacje } \\
\text { finansowe }\end{array}$} & $\begin{array}{l}\text { W różnych elementach każdego raportu finansowego wykorzystywane } \\
\text { są te same dane wejściowe. Interaktywny format danych może zwiększyć } \\
\text { dokładność i rzetelność raportowanych informacji finansowych dzięki } \\
\text { zmniejszeniu potrzeby wielokrotnego wprowadzania tych samych danych, } \\
\text { które mogłoby przyczynić się do powstania błędu. }\end{array}$ \\
\cline { 2 - 2 } & $\begin{array}{l}\text { Dzięki eliminacji konieczności ręcznego wprowadzania danych również } \\
\text { na etapie ich gromadzenia przez użytkowników końcowych może wystąpić } \\
\text { mniejsza liczba błędów. }\end{array}$ \\
\hline
\end{tabular}

Źródło: opracowanie własne na podstawie Interactive Data..., 2009: 130

Po czwarte, dzięki implementacji XBRL może zwiększyć się porównywalność raportów finansowych (raporty mogą być w dowolny i prosty sposób zestawiane, porównywane i interpretowane według wybranych przez odbiorców kryteriów) (tabela 4).

Tabela 4. Wpływ zastosowania XBRL na porównywalność i możliwość interpretacji danych finansowych

\begin{tabular}{|l|l|}
\hline \multicolumn{1}{|c|}{$\begin{array}{c}\text { XBRL } \\
\text { a porównywalność } \\
\text { i interpretacja } \\
\text { danych }\end{array}$} & \multicolumn{1}{c|}{ Wyjaśnienie } \\
\hline \multirow{2}{*}{$\begin{array}{l}\text { Zwiększenie } \\
\text { porównywalności } \\
\text { i możliwości } \\
\text { interpretacji } \\
\text { raportów }\end{array}$} & $\begin{array}{l}\text { Ze względu na stosowanie specjalnych oznaczeń (tagów, etykiet) porów- } \\
\text { nywanie informacji na temat różnych emitentów staje się bardzo proste. }\end{array}$ \\
\cline { 2 - 2 } & $\begin{array}{l}\text { Dzięki elektronicznemu raportowaniu końcowy użytkownik raportów } \\
\text { finansowych może samodzielnie podejmować decyzje interpretacyjne } \\
\text { dotyczące sposobu agregowania analizowanych pozycji finansowych, } \\
\text { nie musi ograniczać się do sposobu agregacji danych finansowych } \\
\text { przedsiębiorstw zaproponowanych przez dostawcę danych. }\end{array}$ \\
\hline
\end{tabular}

Źródło: opracowanie własne na podstawie Interactive Data..., 2009: 130-131

Według US SEC dzięki powyższym korzyściom raportowanie w standardzie XBRL może prowadzić do bardziej efektywnego alokowania kapitału, a w konsekwencji do zwiększenia efektywności rynku kapitałowego. Ponadto interaktywne raportowanie danych zwiększa pokrycie analityczne mniejszych firm, co zwięk- 
sza ich ekspozycję na analityków i inwestorów i w efekcie może przyczyniać się do zmniejszenia kosztu kapitału własnego. Jest też prawdopodobne, że emitenci wykorzystujący format danych interaktywnych na wszystkich etapach swojego cyklu sprawozdawczego mogą w dużym stopniu zwiększyć użyteczność informacji na potrzeby wewnętrzne (Interactive Data..., 2009: 125-131).

28 czerwca 2018 roku US SEC przyjęła nowe zasady raportowania w XBRL. Uznano, że zastosowanie Inline XBRL $L^{1}$ zamiast XBRL może skrócić czas i zmniejszyć wysiłek związany z przygotowywaniem sprawozdań finansowych. Zaznaczono też, że cały czas będzie obserwowany rozwój technologii nadających się do zastosowania $\mathrm{w}$ sprawozdawczości finansowej i w przypadku pojawienia się nowych możliwości będą one rozważane jako ewentualna alternatywa w stosunku do Inline XBRL (Inline XBRL..., 2018: 9).

Interaktywne raportowanie jest również przedmiotem zainteresowania Komisji Europejskiej. W myśl Dyrektywy Parlamentu Europejskiego i Rady 2013/50/ UE z dnia 22 października 2013 roku (Wprowadzenie, pkt 24) ujednolicony elektroniczny format sprawozdawczy może być bardzo korzystny dla emitentów, inwestorów i właściwych organów, ponieważ uprościłby sprawozdawczość oraz ułatwiłby dostępność, analizę i porównywalność rocznych sprawozdań finansowych. Zgodnie z zapisami dyrektywy (art. 4(7)) przygotowywanie rocznych sprawozdań finansowych $\mathrm{w}$ jednolitym elektronicznym formacie sprawozdawczym powinno być obowiązkowe w Unii Europejskiej od 1 stycznia 2020 roku, pod warunkiem, że ESMA dokona odpowiedniej analizy kosztów i korzyści. ESMA powinna opracować projekt regulacyjnych standardów technicznych do przyjęcia przez Komisję, które określałyby elektroniczny format sprawozdawczy, przy należytym uwzględnieniu obecnych i przyszłych możliwości technologicznych, takich jak eXtensible Business Reporting Language (XBRL).

W związku z powyższymi wytycznymi w 2015 roku ESMA przeprowadziła pierwszą analizę kosztów i korzyści związanych z zastosowaniem czterech różnych technologii na potrzeby raportowania w Unii Europejskiej. W jej wyniku ograniczono się do dwóch technologii (XBRL oraz Inline XBRL), a po kolejnych konsultacjach (Consultation Paper..., 2015) wyłoniono Inline XBRL jako ewentualną podstawę elektronicznego formatu sprawozdawczego². W 2016 roku przeprowadzono kolejną analizę kosztów i korzyści (Qualitative, quantitative..., 2016).

1 Inline XBRL to otwarty standard techniczny wymiany danych, oparty na standardzie XBRL. Umożliwia wyświetlanie informacji (pierwotnie przechowywanych w formacie XBRL) przez osadzenie ich w formie tagów (adnotacji) w dokumencie HTML/XHTML. Inline XBRL ma bezpośrednio wpisaną w siebie formę prezentacji czytelną dla użytkownika, nie ma zatem potrzeby dodatkowej prezentacji raportu w innej postaci (np. PDF).

2 W dalszej części artykułu zarówno dla określenia rozwiązań XBRL, jak i Inline XBRL będzie używany termin XBRL. 
ESMA wskazuje, że XBRL spełnia trzy podstawowe warunki wskazane w Dyrektywie Unii Europejskiej (Qualitative, quantitative..., 2016: 15-35; The Cost-Benefit Analysis..., 2016: 59-64).

Po pierwsze, XBRL może uprościć proces raportowania przez przedsiębiorstwa. Dzięki automatyzacji części czynności możliwe jest usprawnienie i ułatwienie sporządzania sprawozdań finansowych.

Po drugie, XBRL może ułatwić dostęp do raportów finansowych ze strony ich użytkowników. Dokumenty XBRL można łatwo odczytać - bez zakupu określonej technologii, ponieważ plik XHTML, w którym osadzone są dane XBRL, można przeglądać za pomocą popularnych przeglądarek internetowych, które są ogólnie dostępne. Ponadto oznaczanie informacji finansowych w raportach za pomocą metadanych XBRL ułatwia użytkownikom znalezienie odpowiednich informacji, ponieważ mogą oni wykorzystać etykiety do zlokalizowania wyszukiwanych informacji. Co więcej, taksonomie XBRL mogą zawierać etykiety w kilku językach. W takim przypadku użytkownicy mogą porównywać pozycje w sprawozdaniach finansowych między emitentami, nawet jeśli emitenci przygotowują swoje sprawozdania finansowe w różnych językach. Różnorodne produkty oprogramowania umożliwiają konwersję informacji XBRL do innych formatów często pożądanych przez użytkowników, takich jak SQL lub Microsoft Excel.

Po trzecie, XBRL może ułatwić analizę i porównywalność raportów finansowych. Dokumenty XBRL zawierają etykiety XBRL, dzięki którym możliwe jest automatyczne wyszukiwanie i analizowanie ogromnych ilości informacji. Umożliwia to inwestorom, analitykom i organom regulacyjnym dostęp do danych finansowych i ich analizowanie, porównywanie ujawnień między emitentami oraz dokonywanie porównań z poprzednimi ujawnieniami od tego samego emitenta. Na przykład poszczególne dane mogą być analizowane w celu obserwacji trendów lub mogą być w dowolny sposób łączone w celu obliczania współczynników lub innych pochodnych wyników.

Poniżej zestawiono szczegółowe aspekty raportowania w XBRL wpływające na uproszczenie procesów sprawozdawczości finansowej, zwiększenie dostępności danych oraz ułatwienie analizy i porównywalności raportów.

Według ESMA zastosowanie XBRL na potrzeby raportowania na rynkach kapitałowych można uznać za korzystne dla emitentów, inwestorów i właściwych organów (Qualitative, quantitative..., 2016: 21-23). Dla emitentów implementacja XBRL może potencjalnie wiązać się z oszczędnościami i redukcją obciążeń administracyjnych. Inwestorzy zyskują dostęp do informacji w ustrukturyzowanym formacie elektronicznym, co zwiększa porównywalność danych (również między krajami) i poprawia możliwości wyszukiwania. Dla regulatorów rynków kapitałowych zastosowanie XBRL wiąże się z automatyzacją, standaryzacją, większą dostępnością, przejrzystością i jakością danych finansowych. 
Tabela 5. Wpływ zastosowania XBRL na uproszczenie procesów sprawozdawczości finansowej, zwiększenie dostępności danych oraz ułatwienie analizy i porównywalności raportów

\begin{tabular}{|c|c|}
\hline $\begin{array}{c}\text { XBRL a procesy } \\
\text { sprawozdawczości, } \\
\text { dostępność } \\
\text { i porównywalność danych }\end{array}$ & Wyjaśnienie \\
\hline $\begin{array}{l}\text { XBRL umożliwia } \\
\text { automatyczne pobieranie } \\
\text { danych do przygotowania } \\
\text { raportów finansowych lub } \\
\text { ich części }\end{array}$ & $\begin{array}{l}\text { Zastosowanie taksonomii XBRL pozwala na mapowanie } \\
\text { danych na poziomie pozycji sprawozdania finansowego lub } \\
\text { szczegółowych ujawnień. Możliwe jest dalsze uszczegóławianie } \\
\text { pozycji raportu, wiązanie z kontami księgi głównej oraz } \\
\text { ustalanie reguł mapowania w celu zautomatyzowania procesu } \\
\text { przygotowywania raportów XBRL. }\end{array}$ \\
\hline $\begin{array}{l}\text { XBRL wspiera proces } \\
\text { przygotowywania raportów } \\
\text { finansowych }\end{array}$ & $\begin{array}{l}\text { Oprogramowanie obsługujące XBRL może zawierać funkcje } \\
\text { ułatwiające raportowanie (np. pozwalające na co najmniej } \\
\text { półautomatyczne generowanie raportów). }\end{array}$ \\
\hline $\begin{array}{l}\text { XBRL może ułatwiać dostęp } \\
\text { do informacji o emitentach } \\
\text { w całej Unii Europejskiej }\end{array}$ & $\begin{array}{l}\text { XBRL może zapewniać nieograniczony dojście do raportów } \\
\text { finansowych pod warunkiem, że infrastruktura IT zapewniająca } \\
\text { dostęp do informacji jest szeroko dostępna i stabilna. } \\
\text { Doświadczenia m.in. Stanów Zjednoczonych, Wielkiej Brytanii } \\
\text { i Danii pokazują, że publikacja danych XBRL zapewnia } \\
\text { większą dostępność informacji finansowych przygotowanych } \\
\text { przez emitentów, dzięki możliwości zastosowania istniejących, } \\
\text { popularnych narzędzi w celu odczytania raportów. }\end{array}$ \\
\hline $\begin{array}{l}\text { XBRL jest powszechnym } \\
\text { formatem elektronicznym, } \\
\text { który może być przesyłany } \\
\text { przez HTTP/HTTPS }\end{array}$ & $\begin{array}{l}\text { Raporty Inline XBRL są plikami zgodnymi z XHTML, które } \\
\text { mogą być przesyłane za pośrednictwem protokołu HTTP/ } \\
\text { HTTPS lub innych. }\end{array}$ \\
\hline $\begin{array}{l}\text { XBRL ułatwia przeglądanie } \\
\text { danych o emitentach } \\
\text { za pomocą popularnych } \\
\text { narzędzi }\end{array}$ & $\begin{array}{l}\text { Raporty XBRL można przeszukiwać przy użyciu standardowej } \\
\text { przeglądarki internetowej. }\end{array}$ \\
\hline $\begin{array}{l}\text { Możliwa jest konwersja } \\
\text { XBRL na inne formaty, } \\
\text { potrzebne i użyteczne dla } \\
\text { użytkowników raportów } \\
\text { finansowych }\end{array}$ & $\begin{array}{l}\text { Możliwe jest przekształcenie plików Inline XBRL na inne } \\
\text { formaty, w tym SQL lub MS Excel. }\end{array}$ \\
\hline $\begin{array}{l}\text { XBRL oferuje dodatkowe } \\
\text { funkcje wspierające } \\
\text { użytkowników danych } \\
\text { w dostępie do treści } \\
\text { raportów finansowych }\end{array}$ & $\begin{array}{l}\text { Przykładem takich funkcji są wielojęzyczne etykiety, które } \\
\text { można opracować dla dowolnej taksonomii XBRL - dzięki } \\
\text { nim możliwe jest porównywanie danych finansowych między } \\
\text { raportami sporządzanymi w różnych językach. }\end{array}$ \\
\hline
\end{tabular}

Źródło: opracowanie własne na podstawie Qualitative, quantitative..., 2016: 15-35 


\section{Korzyści wynikające z zastosowania XBRL na potrzeby raportowania w świetle badań naukowych}

W badaniach naukowych najczęściej wymieniane są następujące potencjalne korzyści wynikające z zastosowania XBRL na potrzeby raportowania finansowego ${ }^{3}$ :

1) zmniejszenie asymetrii informacyjnej między uczestnikami rynku kapitałowego,

2) zwiększenie efektywności informacyjnej oraz zmniejszenie ryzyka informacyjnego na rynku kapitałowym,

3) zwiększenie płynności akcji,

4) redukcja kosztów kapitału własnego,

5) zwiększenie pokrycia analitycznego,

6) zwiększenie zdolności przetwarzania i analizowania danych przez ich użytkowników.

Jednym z potencjalnych skutków zastosowania XBRL na potrzeby raportowania na rynku kapitałowym może być zmniejszenie asymetrii informacyjnej między uczestnikami rynku, wynikające przede wszystkim ze zwiększenia dostępności do danych dla szerszego grona użytkowników ${ }^{4}$.

M.A. Geiger, D.S. North i D.D. Selby (2014) poddali analizie sytuację przedsiębiorstw, które dobrowolnie wdrożyły XBRL jeszcze przed wprowadzeniem w Stanach Zjednoczonych obowiązku implementacji standardu. Próbę badawczą stanowiły 732 raporty kwartalne publikowane w latach 2001-2010 (366 przed zastosowaniem XBRL oraz 366 po zastosowaniu XBRL). Za miarę asymetrii informacyjnej przyjęto bid-ask spread oraz wielkość obrotów w okresie przed i po zastosowaniu standardu XBRL ${ }^{5}$. Wyniki badania potwierdziły zmniejszenie asymetrii informacyjnej, wskazując na znaczne zmniejszenie bid-ask spread dla całej próby badawczej, a także zwiększenie obrotów w grupie dużych przedsiębiorstw.

Kolejne badania dotyczyły pierwszego etapu obowiązkowego zastosowania XBRL w Stanach Zjednoczonych. J.W. Kim, J.H. Lim i W. G. No (2012) ob-

3 Szerzej na temat obszarów badań empirycznych związanych z zastosowaniem XBRL na potrzeby raportowania oraz wniosków z nich płynących patrz Klimczak, 2017a.

4 Szerzej na temat badań dotyczących wpływu XBRL na asymetrię informacyjną na rynku kapitałowym patrz Klimczak, 2017b.

5 Bid-ask spread odnosi się do różnicy między maksymalną ceną oferowaną na rynku za dane aktywa finansowe a minimalną ceną, za jaką sprzedawca może te aktywa sprzedać. Jeśli asymetria informacji na rynku nie istnieje, wszyscy rynkowi gracze mają taki sam zasób informacji i w tej sytuacji bid-ask spread powinien wynosić zero. Im większa asymetria informacji, tym większe różnice w oferowanych cenach zakupu i sprzedaży, czyli tym większy bid-ask spread. Jeśli asymetria informacji zmniejsza się, chęć zakupu i sprzedaży się zwiększa, zwiększając wielkość obrotów. 
jęli badaniem 428 firm (1536 raportów). Badanie dotyczyło roku obrotowego od 15 czerwca 2009 do 14 czerwca 2010 roku. Autorzy badania, porównując sytuację tych samych spółek przed zastosowaniem standardu i po jego zastosowaniu, spodziewali się, że po wdrożeniu standardu XBRL zwiększyła się efektywność informacji oraz zmniejszyło ryzyko informacyjne (mierzone za pomocą zmienności stóp zwrotu wokół dat publikacji raportów 10-K i 10-Q6 ${ }^{7}$. Potwierdzono następujące hipotezy:

1) publikacja raportu w XBRL zmniejsza poziom zmienności stóp zwrotu wokół daty publikacji ;

2) publikacja raportu w XBRL zwiększa poziom efektywności informacyjnej wokół daty publikacji';

3) publikacja raportu w XBRL redukuje zmienność stóp zwrotu wokół daty publikacji ${ }^{10}$.

Badanie zespołu Y. Cong, J. Hao i L. Zou (2014) dotyczyło całego okresu obowiązkowego wdrożenia XBRL w Stanach Zjednoczonych. Próba badawcza obejmowała wszystkie spółki publiczne, które w okresie od 15 czerwca 2009 do 2011 roku wdrożyły standard XBRL. Porównano sytuację każdej spółki sprzed wdrożenia z sytuacją po wdrożeniu standardu. Autorzy wysunęli i potwierdzili hipotezę, że po zastosowaniu standardu XBRL nastąpiło synchroniczne zwiększenie asymetrii informacyjnej (mierzonej za pomocą bid-ask spread) oraz obrotów w krótkim okresie wokół publikacji raportów, co - ich zdaniem - wskazuje, że XBRL sprzyja powstawaniu i przenikaniu idiosynkratycznej informacji na rynek, zwiększając jego efektywność ${ }^{11}$.

Badania nad wpływem XBRL na rynek kapitałowy nie ograniczały się do amerykańskiego rynku. Przykładowo H. Yoon, H. Zo i A.P. Ciganek (2011) zajęli się koreańskim rynkiem kapitałowym. Spółki notowane na KOSPI (Korea

$6 \quad$ Kwartalne raporty wymagane przez US SEC.

7 Zmienność stóp zwrotu może wskazywać na mniejszą lub większą asymetrię informacyjną na rynku kapitałowym - im większa zmienność stóp zwrotu, tym większa asymetria informacyjna.

8 Miarą zmienności jest w tym przypadku ponadprzeciętna stopa zwrotu w dniu $t$, liczona za pomocą modelu.

9 Miarą efektywności jest w tym przypadku odchylenie bezwzględne między rzeczywistą a oczekiwaną stopą zwrotu $\mathrm{z}$ akcji.

10 Miarą zmienności jest w tym przypadku odchylenie standardowe.

11 Autorzy oparli swoje rozważania na koncepcjach i badaniach dotyczących idiosynkratycznej informacji (Kim, Verrecchia, 1994; Krinsky, Lee, 1996; Barron, Byard, Kim, 2002; Barron, Harris, Stanford, 2005). Zgodnie z tymi koncepcjami uczestnicy rynku zbierają prywatne informacje i na ich podstawie formułują idiosynkratyczne przekonania przed publikacją informacji, a następnie rewidują te przekonania po publikacji raportów. Prywatna informacja połączona z publiczną przenika na rynek kapitałowy wtedy, kiedy uczestnicy dokonują transakcji na podstawie swoich zmodyfikowanych przekonań. 
Composite Stock Price Index) i KOSDAQ (Korean Securities Dealers Automated Quotations) mają obowiązek publikowania raportów kwartalnych, śródrocznych i rocznych w standardzie XBRL. Autorzy porównywali sytuację 550 firm w okresie przed obowiązkowym wdrożeniem XBRL (grudzień 2006 - sierpień 2007) oraz po zastosowaniu XBRL (grudzień 2007 - sierpień 2008). Wyniki badania potwierdziły istotną negatywną relację między zastosowaniem XBRL a asymetrią informacyjną. Z kolei badanie Ch. Liu, X. Luo i F.L. Wanga (2017) dotyczyło spółek giełdowych w Belgii w okresie od 2005 do 2010 roku. Zebrano łącznie 28711 obserwacji. Próba obejmowała firmy z różnych branż. Autorzy badania wyciagali wnioski na temat asymetrii informacji przez pomiar płynności rynku ${ }^{12}$. Wyniki badania potwierdziły, że zastosowanie XBRL przez spółki w Belgii znacznie zwiększyło płynność rynku, co może wskazywać, że standard wpłynął na zmniejszenie asymetrii informacyjnej.

Interaktywne dane ułatwiają analitykom $\mathrm{i}$ inwestorom gromadzenie oraz analizowanie dużej ich ilości w krótkim czasie. W związku z tym XBRL może redukować koszt pozyskiwania i przetwarzania informacji, a w konsekwencji prowadzić do zmniejszenia kosztu kapitału własnego. Problem ten był przedmiotem zainteresowania między innymi O.Z. Li, Y. Lina, Ch. Ni (2012). Autorzy przeanalizowali dane ponad 5000 firm, których raporty znalazły się w amerykańskiej bazie EDGAR w okresie 2005-2012. Analiza potwierdziła, że zastosowanie XBRL zwiększa pokrycie analityczne i trafność analiz oraz redukuje zróżnicowanie prognoz analitycznych, a także zwiększa płynność akcji.

Również kolejni badacze - S. Chen, L. Harris, W. Li, D. Wu (2015) - dopatrywali się związku między zwiększeniem możliwości przetwarzania informacji, wynikającym z zastosowania XBRL przez uczestników rynku, a kosztem kapitału własnego. Swoje obserwacje przeprowadzili na chińskim rynku kapitałowym, analizując dane dotyczące spółek notowanych na giełdzie papierów wartościowych w Szanghaju i Shenzhen za okres 2005-2011. Autorzy przewidywali, że XBRL - przez zwiększenie jakości raportowania i zmniejszenie kosztów przetwarzania informacji - może prowadzić do redukcji kosztu kapitału własnego. Na tej podstawie wysunęli hipotezę o pozytywnym wpływie XBRL na redukcję kosztu kapitału własnego, która została potwierdzona.

Zastosowanie XBRL na potrzeby raportowania powoduje, że przetwarzanie i analizowanie informacji staje się tańsze, szybsze oraz bardziej efektywne. W związku z powyższym XBRL może pozytywnie wpływać na pracę analityków rynkowych. Problemem tym interesowali się wspomniani już wcześniej O.Z. Li,

12 Przy niskiej asymetrii informacji inwestorzy są przekonani, że transakcje na rynku odbywają się po „sprawiedliwej” cenie, co pozytywnie wpływa na płynność rynku. Ponadto poprawa jakości informacji może prowadzić do zmniejszenia nakładów, jakie inwestorzy ponoszą w związku z zaangażowaniem w transakcje, co również może zwiększać płynność rynku. Pomiar płynności jest dokonywany przez autorów przy wykorzystaniu modelu. 
Y. Lin, Ch. Ni (2012), ale także K. Ly (2012). Autor ten sprawdził, czy pokrycie analityczne i jakość prognoz analityków zmienia się w okresie po zastosowaniu XBRL w porównaniu z okresem przed zastosowaniem XBRL ${ }^{13}$. Przeanalizował dane dotyczące 338 przedsiębiorstw stosujących US GAAP. W wyniku badania stwierdził, że liczba prognoz analityków co do kwartalnych wyników wzrasta po zastosowaniu XBRL oraz że zróżnicowanie prognoz analityków co do kwartalnych wyników zmniejsza się po wdrożeniu XBRL. Do podobnych wniosków doszli C. Liu, T. Wang, L. J. Yao (2014), którzy poszerzyli pole obserwacji o raporty roczne oraz o kolejne etapy procesu wdrażania XBRL w Stanach Zjednoczonych.

Trafnością prognoz analityków interesowali się także C. Liu i G. O’Farre11 (2013). Zbadali oni dane firm z Belgii, Włoch, Japonii, Singapuru, Hiszpanii oraz Południowej Korei i porównywali trafność prognoz analityków w okresie przed wprowadzeniem obowiązku raportowania w XBRL w wymienionych krajach i po nim. Badanie potwierdziło pozytywny wpływ XBRL na trafność (precyzyjność) prognoz analityków.

Niektórzy badacze analizowali problem technologii XBRL, wpływu jej wykorzystania na efektywność i sprawność wyszukiwania oraz przetwarzania danych przez użytkowników.

Przykładowo: D. J. Janvrin, R.E. Pinsker i M.F. Mascha (2013) przeprowadzili eksperyment, który polegał na powierzeniu grupie jego uczestników zadania dokonania analizy finansowej określonego przedsiębiorstwa wykorzystującego do raportowania alternatywne technologie (w tym XBRL). Większość użytkowników wybrało XBRL ze względu na możliwość szybkiego i sprawnego wykonania zadania. Z kolei F. D. Hodge, J. J. Kennedy i L. A. Maines (2004) analizowali wpływ XBRL na efektywność korzystania z raportów finansowych przez użytkowników. Przeprowadzony przez nich eksperyment pokazał, że osoby, które wykorzystują XBRL, mają większą szansę na odnalezienie odpowiednich informacji w różnych miejscach sprawozdania finansowego w porównaniu z użytkownikami, którzy nie korzystają z XBRL, oraz że uży tkownicy, którzy wykorzystują XBRL są w stanie szybciej połączyć informacje z różnych źródeł (miejsc) sprawozdania finansowego w porównaniu z innymi użytkownikami.

\section{Podsumowanie}

Analizy prowadzone przez regulatorów rynków kapitałowych, a także empiryczne badania naukowe wskazują na szereg korzyści wynikających ze stosowania standardu XBRL na potrzeby raportowania na rynkach kapitałowych. Korzyści

13 Porównywane w badaniu przedziały czasowe obejmowały: okres po zastosowaniu XBRL: wrzesień 2009 - czerwiec 2010 i okres przed zastosowaniem XBRL: wrzesień 2008 - czerwiec 2009. 
te obejmują przede wszystkim zwiększenie ilości i jakości informacji sprawozdawczych przekazywanych ich użytkownikom, a także zwiększenie dostępności tych danych dla użytkowników. Pozytywne konsekwencje mogą być odnotowywane przez wszystkich uczestników procesu wymiany informacji - zarówno zewnętrznych (inwestorów, analityków, nadzorców rynków kapitałowych), jak i wewnętrznych (emitentów raportów opartych na standardzie XBRL). Jednocześnie należy pamiętać, że o ile w skali całej gospodarki czy w skali globalnej korzyści wynikające z zastosowania XBRL mogą wydawać się oczywiste, a sam fakt jego stosowania jest po prostu naturalną konsekwencją postępu technologicznego, od którego nie ma odwrotu, o tyle skala korzyści dla danego środowiska (państwa, rynku kapitałowego) czy wreszcie dla indywidualnego emitenta raportów i ich odbiorcy może być zależna od wielu czynników i uwarunkowań. Ponadto zastosowanie XBRL wiąże się z określonymi kosztami, które muszą być poniesione przez poszczególnych uczestników wymiany informacji (Klimczak, 2018).

18 grudnia 2017 roku ESMA opublikowała raport końcowy na temat technicznego standardu dotyczącego europejskiego jednolitego formatu elektronicznego, w którym zakładany jest obowiązek sporządzania rocznych skonsolidowanych sprawozdań finansowych przez europejskie spółki giełdowe w standardzie XBRL (Final Report..., 2017). Wcześniej, od czerwca do września 2017 roku, przeprowadzono testy terenowe, których celem była ocena, czy rozważane projekty przepisów są wykonalne oraz ustalenie, czy i w jakim stopniu należy je poprawić, aby zwiększyć przydatność danych dla odbiorców raportów XBRL i zmniejszyć obciążenie dla podmiotów je przygotowujących. Testy w terenie zostały zaplanowane jako praktyczne ćwiczenie, w którym 25 europejskich emitentów wolontariuszy przekształciło skonsolidowane sprawozdania finansowe sporządzone według Międzynarodowych Standardów Sprawozdawczości Finansowej w dokumenty XBRL zgodnie ze specyfikacją jednolitego elektronicznego formatu sprawozdawczego, opracowaną przez ESMA. Wyniki warsztatów i ankiety przeprowadzonej po warsztatach umożliwiły ESMA wyciągnięcie wniosku, że wysiłek przygotowania rocznego sprawozdania finansowego w XBRL można uznać za umiarkowany, zwłaszcza biorąc pod uwagę to, że większość uczestników miała ograniczoną wiedzę o XBRL lub w ogóle jej nie posiadała i że przygotowanie pierwszego sprawozdania jest znacznie trudniejsze niż kolejnych. Wnioski z testów terenowych wykorzystano do dalszej poprawy projektu specyfikacji (Final Report..., 2017). ESMA złożyła raport końcowy do Komisji Europejskiej, która podejmie decyzję o ewentualnym zatwierdzeniu standardu technicznego. Jeśli standard zostanie przyjęty, do przedsiębiorstw do tej pory wykorzystujących standard obligatoryjnie lub dobrowolnie dołączy duża grupa podmiotów, co będzie kolejnym krokiem na drodze do rozpowszechnienia XBRL na świecie jako narzędzia komunikacji sprawozdawczości finansowej. 


\section{Bibliografia}

Barron O.E., Byard D., Kim O. (2002), Changes in analysts' information around earnings announcements, „The Accounting Review”, t. 77(4), s. 821-846.

Barron O.E., Harris D. G., Stanford M. (2005), Evidence that investors trade on private event-period information around earnings announcements, „The Accounting Review”, t. 80(2), s. 403-421.

Boritz J.E., No W.G. (2003), Assurance Reporting for XBRL: XARL (eXtensible Assurance Reporting Language), [w:] S.J. Roohani (ed.), Trust and Data Assurances in Capital Markets: The Role of Technology Solutions, Pricewaterhouse Coopers, Smithfield, s. 17-31.

Chen S., Harris L., Li W., Wu D. (2015), How Does XBRL Affect the Cost of Equity Capital? Evidence from an Emerging Market, ,Journal of International Accounting Research American Accounting Association", t. 14, nr 2, s. 123-145.

Cong Y., Hao J., Zou L. (2014), The Impact of XBRL Reporting on Market Efficiency, ,Journal of Information Systems", t. 28, nr 2, s. 181-207.

Consultation Paper on Draft Regulatory Technical Standards on European Single Electronic Format (2015), ESMA, https://www.esma.europa.eu/press-news/consultations/consultation-paper-european-single-electronic-format (dostęp: 17.03.2018).

Dyrektywa Parlamentu Europejskiego i Rady 2013/50/UE z dnia 22 października 2013 r. zmieniająca dyrektywę 2004/109/WE Parlamentu Europejskiego i Rady w sprawie harmonizacji wymogów dotyczących przejrzystości informacji o emitentach, których papiery wartościowe dopuszczane są do obrotu na rynku regulowanym, dyrektywę 2003/71/WE Parlamentu Europejskiego i Rady w sprawie prospektu emisyjnego publikowanego w związku z publiczną ofertą lub dopuszczeniem do obrotu papierów wartościowych oraz dyrektywę Komisji 2007/14/WE ustanawiającą szczegółowe zasady wdrożenia niektórych przepisów dyrektywy 2004/109/WE.

Final Report on the RTS on the European Single Electronic Format (2017), ESMA, https://www. esma.europa.eu/policy-activities/corporate-disclosure/european-single-electronic-format (dostęp: 17.03.2018).

Geiger M.A., North D. S., Selby D.D. (2014), Releasing Information in XBRL: Does It Improve Information Asymmetry for Early U.S. Adopters?, „Academy of Accounting and Financial Studies Journal", t. 18, nr 4, s. 66-83.

Hodge F.D., Kennedy J.J., Maines L.A. (2004), Does Search-Facilitating Technology Improve the Transparency of Financial Reporting? „The Accounting Review”, t. 79, nr 3, s. 687-703.

http://www.xbrl.org (dostęp: 17.03.2018).

Inline XBRL Filing of Tagged Data (2018), SEC Release No. 33-10514; 34-83551, https://www.sec. gov/rules/final/2018/33-10514.pdf (dostęp: 17.03.2018).

Interactive Data to Improve Financial Reporting (2009), SEC Release No. 33-9002, https://www. sec.gov/rules/final/2009/33-9002.pdf (dostęp: 17.03.2018).

Janvrin D.J., Pinsker R.E., Mascha M.F. (2013), XBRL-Enabled, Spreadsheet, or PDF? Factors Influencing Exclusive User Choice of Reporting Technology, „Journal of Information Systems", t. 27, nr 2, s. 35-49.

Kim J.W., Lim J.H., No W.G. (2012), The Effect of First Wave Mandatory XBRL Reporting Across the Financial Information Environment, „, Journal of Information Systems American Accounting Association", t. 26, nr 1, s. 127-153.

Kim O., Verrecchia R. (1994), Market liquidity and t.me around earnings announcements, „Journal of Accounting \& Economics", t. 17(1/2), s. 41-67.

Klimczak K. (2017a), XBRL jako narzędzie raportowania finansowego - główne nurty badań empirycznych, „Studia Ekonomiczne. Zeszyty Naukowe Uniwersytetu Ekonomicznego w Katowicach", nr 333, s. 125-138. 
Klimczak K. (2017b), Wptyw XBRL na asymetrię informacyjna na rynku kapitałowym, „Finanse, Rynki Finansowe, Ubezpieczenia", nr 4(88), s. 293-301.

Klimczak K. (2018), Koszty oraz uwarunkowania implementacji XBRL jako standardu raportowania finansowego na rynkach kapitałowych, artykuł przyjęty do publikacji w ,Zeszytach Teoretycznych Rachunkowości".

Krinsky I., Lee J. (1996), Earnings announcements and the composition of the bid-ask spread, „Journal of Finance”, t. 51(4), s. 1523-1535.

Li O.Z., Lin Y., Ni Ch. (2012), Does XBRL Adoption Reduce the Cost of Equity Capital?, http:// www.researchgate.net/publication/256031257_Does_XBRL_Adoption_Reduce the Cost of_Equity_Capital (dostęp: 17.03.2018).

Liu C., O'Farrell G. (2013), The Role of Accounting Values in the Relation between XBRL and Forecast Accuracy, „International Journal of Accounting \& Information Management”, t. 21(4), s. 297-313.

Liu C., Wang T., Yao L.J. (2014), XBRL's Impact on Analyst Forecast Behavior: An Empirical Study, „Journal of Accounting and Public Policy”, t. 33(1), s. 69-82.

Liu Ch., Luo X., Wang F.L. (2017), An Empirical Investigation on the Impact of XBRL Adoption on Information Asymmetry: Evidence from Europe, „Decision Support Systems”, nr 93, s. $42-50$.

Ly K. (2012), Extensible Business Reporting Language for Financial Reporting and Financial Analysts' Activity: Early Evidence, „Academy of Accounting and Financial Studies Journal”, t. 16 , nr 2, s. 25-44.

Qualitative, quantitative and technological assessment of the appriopriatness of the iXBRL technology for the ESEF (2016), [w:] Feedback Statement on the Consultation Paper on the Regulatory Technical Standard on the European Single Electronic Format (ESEF), European Securities and Markets Authority, https://www.esma.europa.eu/sites/default/files/library/2016-1668 esma_feedback_statement_on_the_rts_on_esef_0.pdf (dostęp: 17.03.2018).

The Cost-Benefit Analysis for the Regulatory Technical Standard on the European Single Electronic Format (2016), [w:] Feedback Statement on the Consultation Paper on the Regulatory Technical Standard on the European Single Electronic Format (ESEF), European Securities and Markets Authority, https://www.esma.europa.eu/sites/default/files/library/2016-1668_esma_ feedback_statement_on_the_rts_on_esef_0.pdf (dostęp: 17.03.2018).

Yoon H., Zo H., Ciganek A.P. (2011), Does XBRL Adoption Reduce Information Asymmetry? „Journal of Business Research", nr 64, s. 157-163.

\title{
The Benefits of Using XBRL for Reporting on Capital Markets in the Light of Market Supervisors Reports and Scientific Research
}

\begin{abstract}
The aim of the article is to identify the most important benefits associated with the use of XBRL for the needs of reporting on capital markets enumerated and analyzed by supervisors of these markets and verified in empirical scientific research. Analyzes and research indicate that the use of the XBRL standard as a tool supporting financial reporting can improve the flow of information, increase the quality and quantity of data available to recipients, increase the comparability of financial statements, increase the ability of users to process and analyze data. The standard may have a major impact on the functioning of the capital market by reducing information asymmetry between mar-
\end{abstract}


ket participants, reducing costs of equity, increasing market liquidity. The benefits of using XBRL can be noted by all participants of the capital markets - enterprises financing their operations through these markets, market regulators, investors and analysts.

Keywords: XBRL, reporting, capital markets, benefits

JEL: M41

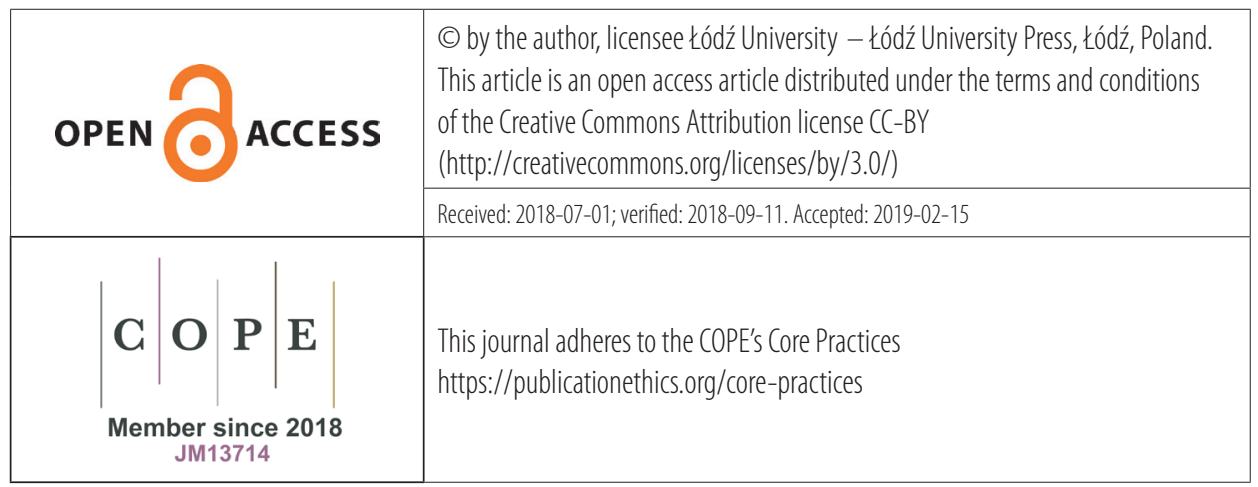

